\title{
Catecholamine Receptor Sensitivity and the Regulation of Lipolysis in Adult Diabetes
}

\author{
J. P. D. Reckless and D. J. Galton \\ Diabetes and Lipid Research Laboratory, St. Bartholomew's Hospital, London, England
}

\begin{abstract}
Summary. The sensitivity of alpha- and beta-adrenergic receptors, and the antilipolytic actions of prostaglandin $E_{1}$ or insulin on adipose tissue of obese diabetic and non-diabetic subjects have been studied. Accumulation of cyclic AMP in adipose tissue and release of glycerol in response to several catecholamines (adrenaline, noradrenaline and isoprenaline) in the presence or absence of an alpha-adrenergic blocker (phentolamine) have been used to assess catecholamine receptor sensitivity. No differences in betareceptor activity were observed between diabetics and non-diabetics, either on glycerol release or accumulation of cyclic AMP; alpha-receptor activity was also similar, except for significantly less accumulation of cyclic AMP in diabetic tissue incubated with noradrenaline and phentolamine $(\mathrm{p}<0.01)$. The antilipolytic action of prostaglandin $\mathrm{E}_{1}$ (at concentrations of $30 \mathrm{fM}$ to $30 \mathrm{pM}$ ) on lipolysis (stimulated submaximally with isoprenaline, $10^{-7} \mathrm{M}$ ) was similar in diabetic and control groups. The antilipolytic action of insulin (from $10^{-10}$ to $10^{-6} \mathrm{M}$ ) on lipolysis was also similar between the groups. It is concluded that neither disorders of the catecholamine receptor nor of the antilipolytic actions of prostaglandin $E_{1}$ or insulin are responsible for the abnormalities of fatty acid metabolism in adult diabetes.
\end{abstract}

Key words: Alpha-receptor, beta-receptor, catecholamines, prostaglandin, insulin, cyclic AMP, lipolysis, diabetes.

Congenital and acquired disorders of catecholamine receptors have been recently described in association with several diseases. Thus, in triglyceride storage disease there appears to be a defect in the activation of adenyl cyclase in adipocytes by catecholamines and this may be due to a defect of the beta-receptor (or associated adenyl cyclase) and relate to the abnormal accumulation of triglyceride in this condition [1]. In hypothyroidism there is increased activity of the alpha-receptor of adipocytes so that stimulation with catecholamines (noradrenaline or adrenaline) results in an impaired increment of glycerol compared either to euthyroid controls [2] or to hypothyroid tissue stimulated by a predominant beta-agonist such as isoprenaline [3]. The receptor defect in hypothyroidism is reversible with thyroxine therapy [4] and may contribute to the low levels of plasma fatty acids observed in hypothyroidism.

It has recently been suggested that in adult diabetes there is impaired sensitivity of the beta-receptor of adipocytes, as judged by a reduced output of glycerol from adipose tissue following incubation with adrenaline and phentolamine [5]. Such a defect would be expected to lead to a decreased release of fatty acid from the tissue. Since the levels and turnover of plasma fatty acids are primarily determined by the release from the adipose organ [6] a reduced beta-receptor activity would be expected to lead to reduced levels of plasma fatty acids. In fact, the opposite usually occurs in adult diabetes, where raised plasma fatty acid levels (and turnover) have been reported [7]. In an attempt to resolve the discrepancy between reports of impaired beta receptor activity in adipose tissue and increased levels and turnover of fatty acids in adult diabetes, we have studied the sensitivity of the catecholamine receptors to adrenaline, noradrenaline and isoprenaline and the regulation of lipolysis by insulin and prostaglandin $E_{1}$ in adipose tissue of adult diabetics.

\section{Material and Methods}

Patients studied were overweight, with untreated diabetes mellitus of maturity onset. They were not 
Table 1. Clinical and biochemical details of patient groups

\begin{tabular}{|c|c|c|c|c|c|c|c|c|}
\hline Patients & $n$ & $\begin{array}{l}\text { Age } \\
\text { (years) }\end{array}$ & $\begin{array}{l}\text { Height } \\
(\mathrm{cm})\end{array}$ & $\begin{array}{l}\text { Weight } \\
\text { (kg) }\end{array}$ & $\begin{array}{l}\text { Percent of } \\
\text { desirable weight }\end{array}$ & $\begin{array}{l}\text { Adipocyte } \\
\text { diameter }(\mu \mathrm{m})\end{array}$ & $\begin{array}{l}\text { Fasting blood } \\
\text { glucose (mM) }\end{array}$ & $\begin{array}{l}\text { Plasma } \\
\text { insulin }(\mu \mathrm{U} / \mathrm{ml})\end{array}$ \\
\hline $\begin{array}{l}\text { A } \\
\text { Diabetic } \\
\text { Non-diabetic } \\
\text { P }\end{array}$ & $\begin{array}{l}21 \\
11\end{array}$ & $\begin{array}{l}55 \pm 3 \\
38 \pm 4 \\
<0.002\end{array}$ & $\begin{array}{l}168 \pm 2 \\
166 \pm 3\end{array}$ & $\begin{array}{r}89 \pm 3 \\
105 \pm 7\end{array}$ & $\begin{array}{l}151 \pm 7 \\
181 \pm 10 \\
<0.02\end{array}$ & $\begin{array}{l}102 \pm 2 \\
105 \pm 3\end{array}$ & $\begin{array}{l}8.9 \pm 0.6 \\
4.5 \pm 0.1 \\
<0.01\end{array}$ & $\begin{array}{l}20 \pm 2 \\
13 \pm 2 \\
<0.05\end{array}$ \\
\hline $\begin{array}{l}\text { B } \\
\text { Diabetic } \\
\text { Non-diabetic } \\
\text { P }\end{array}$ & $\begin{array}{r}14 \\
7\end{array}$ & $\begin{array}{l}53 \pm 3 \\
37 \pm 4 \\
<0.01\end{array}$ & $\begin{array}{l}161 \pm 3 \\
161 \pm 2\end{array}$ & $\begin{array}{r}90 \pm 7 \\
109 \pm 9\end{array}$ & $\begin{array}{l}152 \pm 6 \\
206 \pm 20 \\
<0.01\end{array}$ & $\begin{array}{l}105 \pm 4 \\
114 \pm 3\end{array}$ & $\begin{array}{l}8.1 \pm 0.9 \\
4.4 \pm 0.2 \\
<0.02\end{array}$ & $\begin{array}{l}14 \pm 2 \\
22 \pm 3 \\
<0.05\end{array}$ \\
\hline $\begin{array}{l}\mathrm{C} \\
\text { Diabetic } \\
\text { Non-diabetic } \\
\mathbf{P}\end{array}$ & $\begin{array}{l}19 \\
11\end{array}$ & $\begin{array}{l}48 \pm 3 \\
45 \pm 5\end{array}$ & $\begin{array}{l}167 \pm 2 \\
162 \pm 2\end{array}$ & $\begin{array}{r}98 \pm 5 \\
105 \pm 5\end{array}$ & $\begin{array}{l}165 \pm 11 \\
194 \pm 7\end{array}$ & $\begin{array}{l}100 \pm 2 \\
109 \pm 2 \\
0.01\end{array}$ & $\begin{array}{l}7.3 \pm 0.6 \\
4.4 \pm 0.1 \\
<0.001\end{array}$ & $\begin{array}{l}16 \pm 2 \\
15 \pm 2\end{array}$ \\
\hline $\begin{array}{l}\text { D } \\
\text { Diabetic } \\
\text { Non-diabetic } \\
\text { P }\end{array}$ & $\begin{array}{l}19 \\
11\end{array}$ & $\begin{array}{l}48 \pm 3 \\
44 \pm 5\end{array}$ & $\begin{array}{l}167 \pm 2 \\
161 \pm 2\end{array}$ & $\begin{array}{r}97 \pm 5 \\
105 \pm 5 \\
0.05\end{array}$ & $\begin{array}{l}165 \pm 11 \\
194 \pm 7\end{array}$ & $\begin{array}{l}100 \pm 2 \\
109 \pm 2 \\
0.01\end{array}$ & $\begin{array}{l}7.3 \pm 0.6 \\
4.4 \pm 0.1 \\
<0.01\end{array}$ & $\begin{array}{l}16 \pm 2 \\
15 \pm 2\end{array}$ \\
\hline
\end{tabular}

Results are means \pm SEM and significance of differences were assessed by the Student's test. Percent of desirable weight was calculated from tables of desirable weights of adults (from statistical bulletin of the Metropolitan Life Insurance Co. 1959)

keto-acidotic, were not insulin-dependent, and were not receiving medication known to alter carbohydrate or lipid metabolism. Obese non-diabetic subjects were studied as controls. All subjects were admitted to hospital and examined after an overnight fast of fourteen hours. The clinical and biochemical details of each of the patient groups are presented in Table 1. Group A was examined for catecholamine sensitivity; group $B$ for effects of prostaglandin $\mathrm{E}_{1}$ on lipolysis; group $C$ for the effects of insulin on lipolysis; and group $D$ for effects of insulin or prostaglandin $E_{1}$ on cyclic AMP accumulation in adipose tissue.

\section{Samples}

Adipose tissue (500-800 mg) was obtained by needle biopsy [8] from the anterior abdominal wall, distant to $0.5 \mathrm{ml}$ of intradermal $0.04 \mathrm{M}$ lignocaine. This avoided as far as possible contamination of adipose tissue by local anaesthetic, which may depress lipolysis [20]. Possible contamination was eliminated by washing tissue samples in $0.15 \mathrm{M}$ saline.

Blood was taken for estimation of plasma lipids, insulin and blood glucose, and was followed by a $50 \mathrm{~g}$ oral glucose tolerance test. Values of blood glucose at 0,60 and 120 minutes, above $5.5,10$ and $6.6 \mathrm{mM}$ respectively were considered abnormal. All diabetic patients had at least two abnormal values.

\section{Methods}

Blood glucose was measured by an automated method using neocuproine copper agent [9]. Plasma insulin was measured by a solid phase radioimmunoassay kit (Pharmacia A. B., Uppsala, Sweden).

Glycerol release from adipose tissue into the incubation medium was estimated by an enzymic method [10]. Fatty acids were measured in the incubation media by a fluorimetric method [11].

\section{Tissue Incubations}

For glycerol release, tissue samples were pre-incubated for 30 minutes at $37^{\circ} \mathrm{C}$ in Earle's bicarbonate buffer ( $\mathrm{pH} 7.4$ ) with $1 \mathrm{~g}$ per $100 \mathrm{ml}$ crystalline bovine plasma albumin, under a gas phase of $\mathrm{O}_{2}: \mathrm{CO}_{2}(95: 5)$. Samples were then incubated for 60 or 120 minutes in fresh buffer with appropriate additions. Fatty acid release was measured from similarly treated samples, with incubation for 120 minutes.

Cyclic AMP levels were measured in adipose tissue samples which had been pre-incubated for 30 minutes, and incubated for 5 minutes in the presence of appropriate additions, and in the presence of $10^{-2}$ $M$ theophylline for the whole period. At the end of 5 minutes incubation the accumulation of cyclic AMP was terminated by the addition of the sample to ice-cold $0.7 \mathrm{M} \mathrm{HCl}$. Samples were homogenised in 


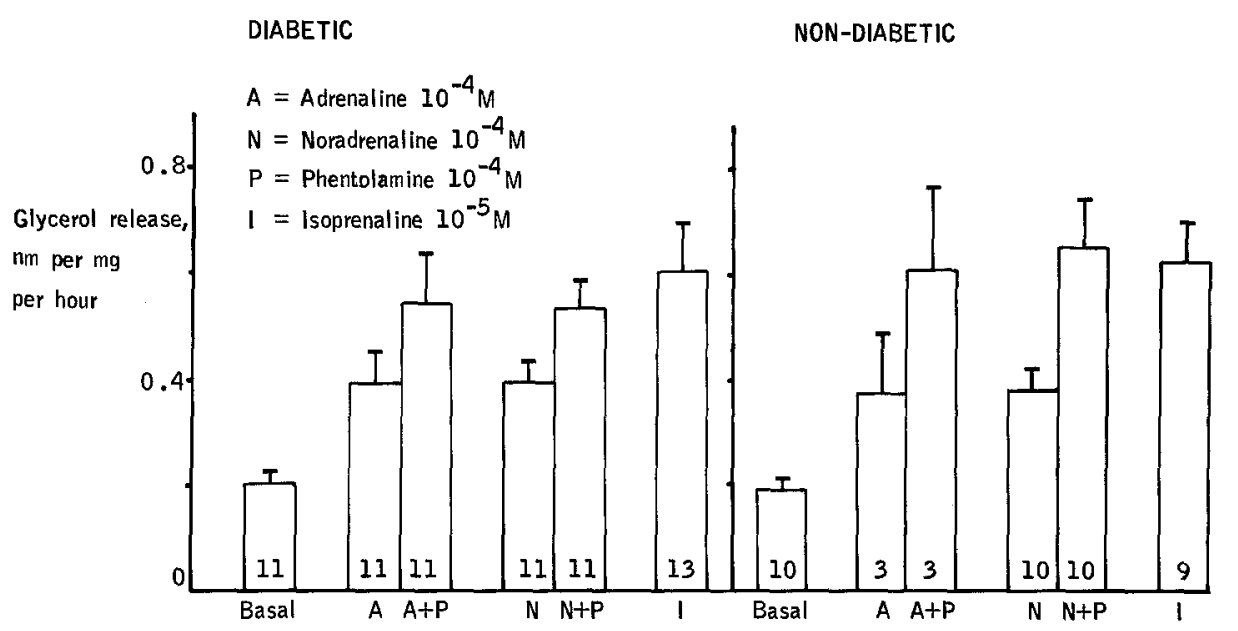

Fig. 1. Glycerol release from adipose tissue of diabetic and non-diabetic patients. Adipose tissue (50-100 mg) was preincubated for $30 \mathrm{~min}$ in Earle's bicarbonate buffer ( $\mathrm{pH} 7.4)$ containing bovine crystalline albumin ( $1 \mathrm{gper} 100 \mathrm{ml})$; and then incubated in Earle's buffer ( $250 \mu \mathrm{l})$ for a further $60 \mathrm{~min}$ with appropriate hormone and chemical additions. At the end of incubation tissue was removed and the incubation medium stored at $-20^{\circ} \mathrm{C}$ till assay for glycerol. Bars represent means + SEM with number of patients

triethanolamine buffer and petroleum ether, and after neutralisation with $2.8 \mathrm{M} \mathrm{KOH}$ the extract was stored at $-20^{\circ} \mathrm{C}$ until assayed by a competitive proteinbinding assay [12].

\section{Determination of Adipocyte Size}

Adipose tissue $(35-45 \mathrm{mg}$ ) was incubated in Earle's buffer in the presence of collagenase (Worthington Biochemical Corporation) to isolate adipocytes. Aliquots of cells were photographed on siliconised glass slides with a Zeiss microscope using Polaroid film. The diameter of at least 300 individual cells was estimated. The volume of each cell was calculated and then the average volume for the sample determined. Assuming the density of fat cells to be $0.915 \mathrm{~g} / \mathrm{ml}$ the average weight of fat cells in the tissue was estimated. From the total weight of lipid an estimate of the cell number in the incubated adipose tissue samples was calculated. It has been previously reported that the diameter of cells liberated by collagenase digestion [18] corresponds closely to the diameter of cells of intact tissue slices $(\mathrm{r}=0.94, \mathrm{n}=11)$.

\section{Results}

Human adipocytes contain both alpha- (inhibitory) and beta- (stimulatory) adrenergic receptors [21]. Adrenaline and noradrenaline produce a net betastimulatory effect, so the actions of these catecholamines alone and in the presence of the alphablocking agent phentolamine were examined on accumulation of cyclic AMP and release of glycerol. The effects of antilipolytic agents, prostaglandin $E_{1}$ and insulin on lipolysis, stimulated submaximally with isoprenaline, were also studied.

\section{Catecholamines and Lipolysis}

In both diabetic and non-diabetic patients (group A in Table 1) glycerol release was increased by incubation of tissue with either adrenaline or noradrenaline (Fig. 1). Lipolysis was increased further by the presence of phentolamine with the catecholamine, to levels of glycerol release similar to those obtained with the predominantly beta agonist isoprenaline (Fig. 1). No differences were seen between diabetic and nondiabetic groups. In particular there was no evidence for increased sensitivity of diabetic adipose tissue to catecholamines at the concentrations used; nor was there evidence for impaired sensitivity of adipose tissue from diabetics to stimulation by catecholamines with phentolamine. In the same groups of patients adipose tissue was examined for accumulation of cyclic AMP in the presence of the same catecholamines (Fig. 2). Cyclic AMP levels were increased by noradrenaline and adrenaline, and levels were further increased in the presence of phentolamine. The levels of cyclic AMP accumulated in adipose tissue from diabetic patients in the presence of noradrenaline with phentolamine were significantly lower than levels in the non-diabetic tissue ( $p<0.01$ ), although levels of cyclic AMP were similar between the groups with adrenaline and phentolamine.

As varying degrees of adipocyte size are known to affect rates of lipolysis [19], the results were examined as activities per million adipocytes (results not pre- 
DIABETIC

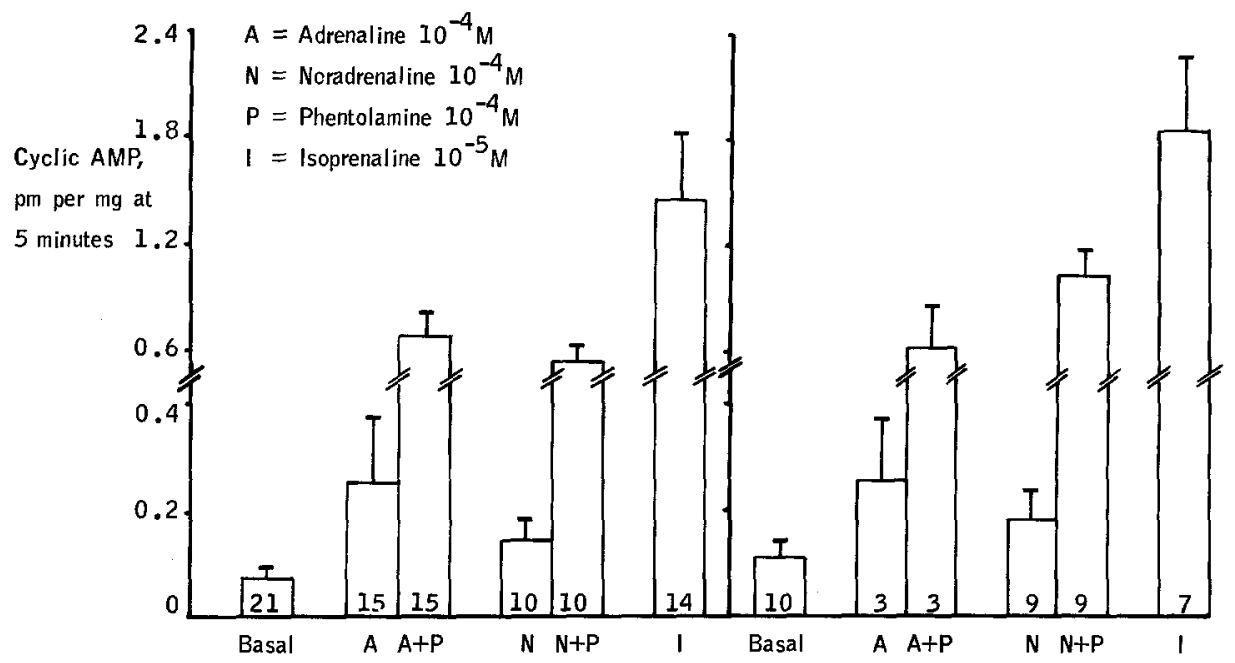

Fig. 2. Cyclic AMP accumulation in adipose tissue of diabetic and non-diabetic patients. Adipose tissue (50-100 mg) was preincubated for 30 min in Earle's bicarbonate buffer ( $\mathrm{pH} \mathrm{7.4)}$ containing bovine crystalline albumin $(1 \mathrm{~g}$ per $100 \mathrm{ml})$ and theophylline (10 mM); and then incubated for a further five min in Earle's bicarbonate buffer with theophylline $10 \mathrm{mM}$ and appropriate hormone and chemical additions. The reaction was terminated by addition of the tissue sample to $200 \mu \mathrm{l}$ of ice-cold $\mathrm{HCl}(0.7 \mathrm{M})$ and cyclic $\mathrm{AMP}$ assayed as described in Methods. Bars represent means + SEM with number of patients

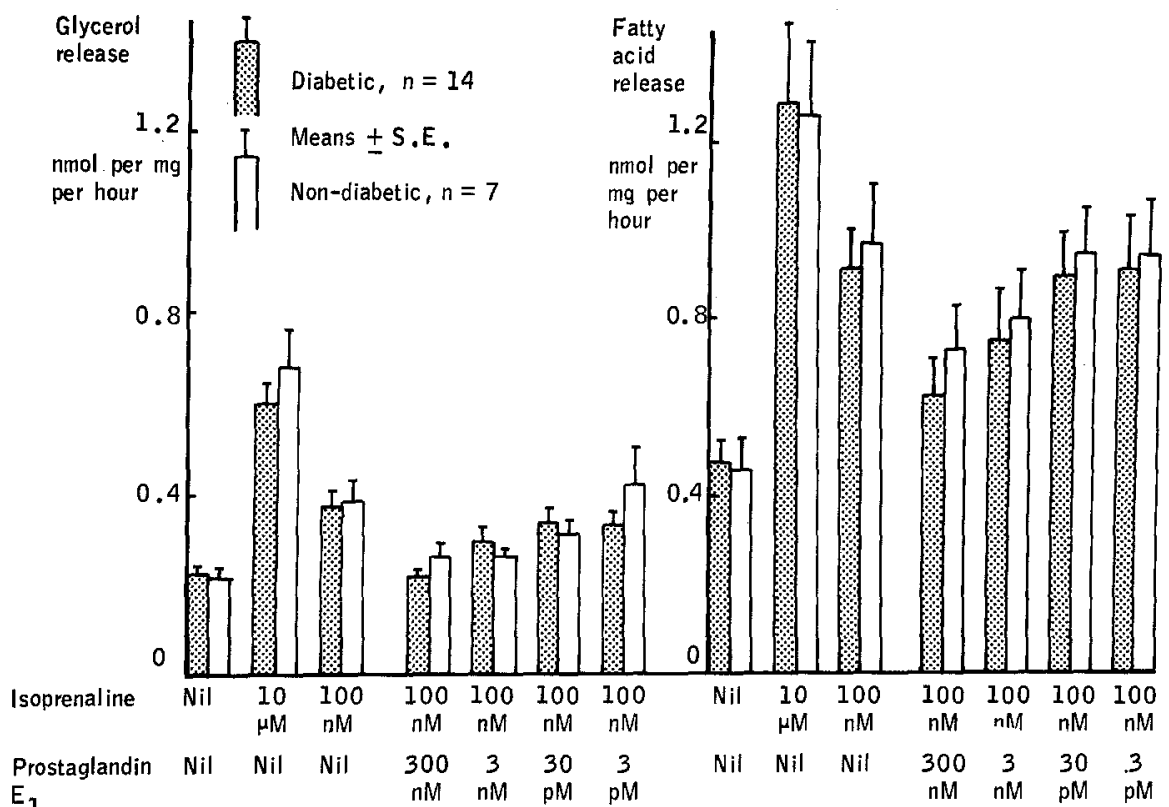

Fig. 3. The effect of prostaglandin $E_{1}$ on glycerol and fatty acid release from adipose tissue stimulated in vitro by isoprenaline. Incubation conditions were similar to Figure 1. Compared to glycerol release in the presence of isoprenaline $10^{-7} \mathrm{M}$

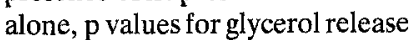
with prostaglandin $\mathrm{E}_{1}$ at $300 \mathrm{nM}, 3$ $\mathrm{nM}$ and $30 \mathrm{pM}$ are $0.004,0.065$ and 0.07 respectively in the non-diabetic; and in the diabetic are 0.001 and 0.03 at concentrations of $300 \mathrm{nM}$ and 3 $\mathrm{nM}$. Fatty acid release decreases in the diabetic $(p=0.002$ and 0.013$)$ and non-diabetic $(p=0.003$ and 0.03 ) with prostaglandin $E_{1}$ levels of $300 \mathrm{nM}$ and $3 \mathrm{nM}$ sented). No differences were demonstrated between the two groups of subjects for rates of glycerol release, but a smaller accumulation of cyclic AMP after stimulation by noradrenaline with phentolamine was again observed in diabetic tissue $(\mathrm{p}<0.02)$. However, the beta-agonist isoprenaline elevated tissue levels of cyclic AMP to a similar extent in diabetic and nondiabetic tissues.

\section{Antilipolytic Agents and Lipolysis}

a. Prostaglandin $E_{1}$. The inhibitory effects of prostaglandins on lipolysis are best observed when the lipolytic pathway is submaximally stimulated. Effects of prostaglandin $\mathrm{E}_{1}$ were therefore studied in adipose tissue (of patients in group B, Table 1) stimulated by isoprenaline $\left(10^{-7} \mathrm{M}\right)$, a concentration which stimu- 


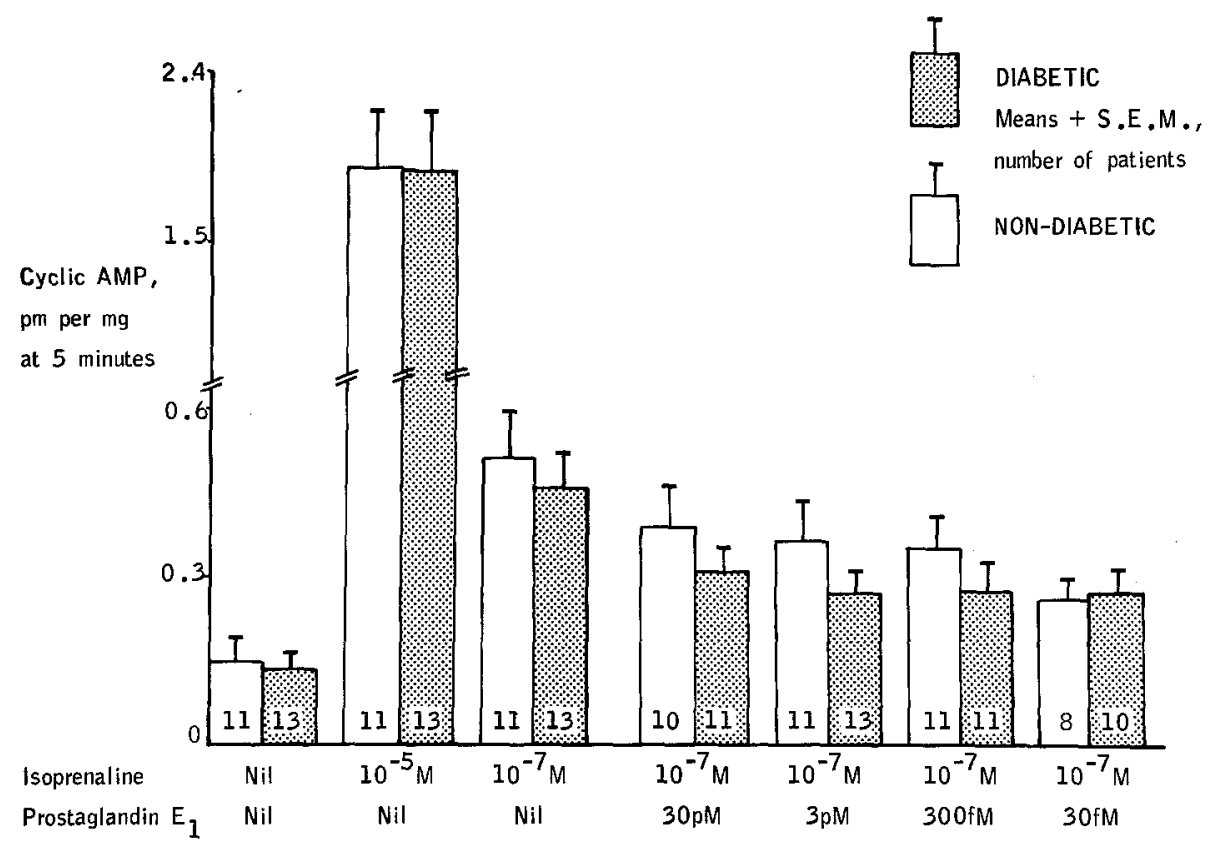

Fig. 4. The effect of prostaglandin $E_{1}$ on cylic AMP accumulation in adipose tissue of diabetic and non-diabetic patients. Incubation conditions were as in Figure 2. Bars represent means + SEM with number of patients

lated lipolysis submaximally (Fig. 3). No significant differences were observed between diabetic and nondiabetic groups in the release of glycerol or fatty acids, but it was found that prostaglandin $E_{1}$ was a very effective agent in reducing rates of both glycerol and fatty acid release at $3 \times 10^{-7} \mathrm{M}$ and $3 \times 10^{-9} \mathrm{M}$ concentrations, whether results are expressed per $\mathrm{mg}$ wet weight of tissue (Fig. 3) or per $10^{6}$ adipocytes (results not presented).

Prostaglandin $\mathrm{E}_{1}\left(3 \times 10^{-11} \mathrm{M}\right.$ and $\left.3 \times 10^{-14} \mathrm{M}\right)$ also inhibited the accumulation of cyclic AMP in adipose tissue from patients in Group D (Table 1) in the presence of submaximal concentrations of isoprenaline (Fig. 4). This potent effect is seen at concentrations much lower than those which inhibit lipolysis and are equivalent to about 100 molecules of prostaglandin $\mathrm{E}_{1}$ per adipocyte; the difference could be due to rapid degradation of prostaglandins in the incubation system, which would favour an effect on accumulation of cylic AMP (measured during $5 \mathrm{mi}$ nutes) rather than on release of fatty acids (measured during 2 hours). No differences were observed between diabetic and non-diabetic groups, whether expressed on a mg wet weight (Fig. 4) or $10^{6}$ cell basis (results not shown).

b. Insulin. The effect of insulin was studied on rates of glycerol and fatty acid release from adipose tissue (of patients in group $\mathrm{C}$, Table 1) submaximally stimulated by isoprenaline $\left(10^{-7} \mathrm{M}\right)$. Physiological $\left(10^{-10} \mathrm{M}\right.$,
13.2 $\mu \mathrm{U} / \mathrm{ml})$ and pharmacological $\left(10^{-6} \mathrm{M}\right.$ and $10^{-8}$ $\mathrm{M})$ concentrations of insulin lowered glycerol release in both diabetic and non-diabetic patients to a similar extent (Fig. 5). Release of fatty acids from adipose tissue was also lowered by insulin in both groups of patients, with the exception of the diabetic group using insulin at $10^{-10} \mathrm{M}$ (Fig. 5). Similarly, insulin at $10^{-6}, 10^{-8}$ and $10^{-10} \mathrm{M}$ produced falls in tissue levels of cyclic AMP and no significant differences were observed between diabetic and non-diabetic groups (Fig. 6).

\section{Discussion}

Our data fail to demonstrate an alteration in catecholamine-receptor sensitivity of adipose tissue from adult diabetics. The catecholamine receptor in our experiments is considered as a regulatory "subunit" of adenyl cyclase and receptor sensitivity is measured as changes in the activity of adenyl cyclase following combination with ligand. Beta-receptor sensitivity is measured by the accumulation of cyclic AMP, and alpha-receptor sensitivity by the decrease in tissue levels of cyclic AMP following incubation with catecholamine in the absence of an alpha-blocking agent (phentolamine). Also the effects of catecholamines on stimulation of glycerol and fatty acid release from adipocytes have been examined; under all conditions the activity of the betareceptor 


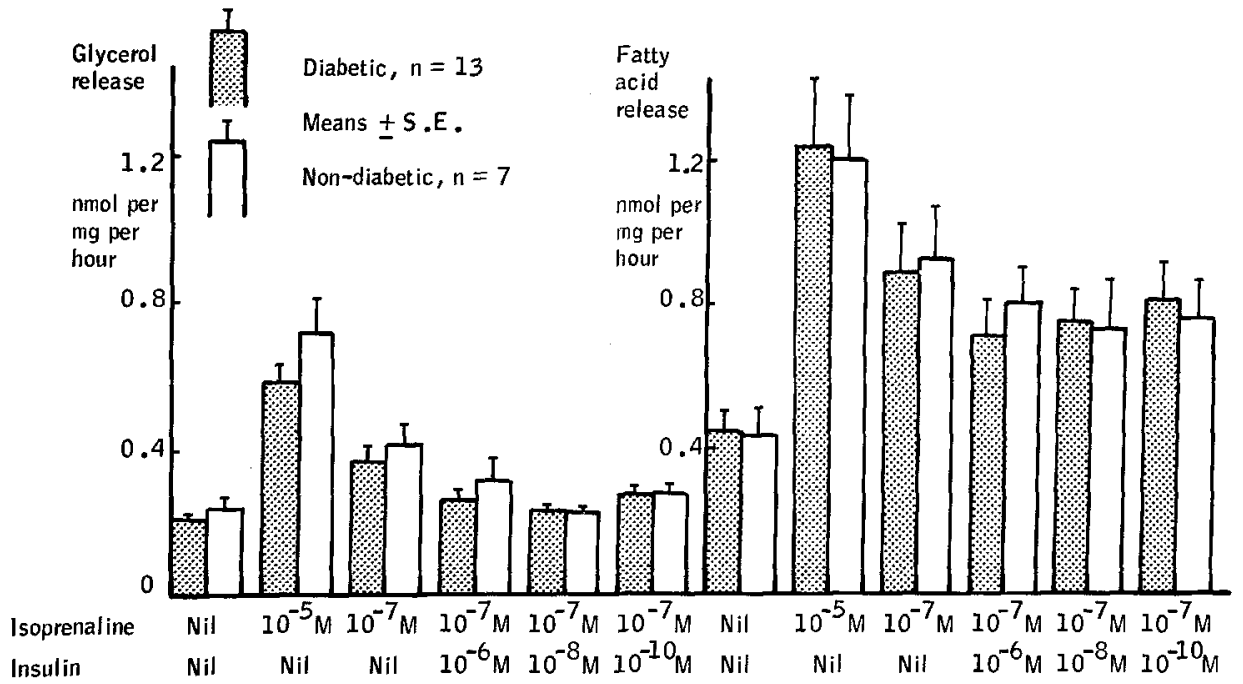

Fig. 5. The effect of insulin on glycerol and fatty acid release from adipose tissue of diabetic and non-diabetic patients. Incubation conditions were as in Figure 1. Glycerol release is reduced by insulin at $10^{-6}, 10^{-8}$ and $10^{-10} \mathrm{M}$ in the diabetics ( $\mathrm{p}=0.003,0.001$ and 0.02 respectively) and in non-diabetics $(p=0.058,0.013$ and 0.027$)$. Fatty acid release fell in non-diabetics $\left(p=0.03,0.004\right.$ and 0.01 respectively), and at $10^{-6}$ $\mathrm{M}$ and $10^{-8} \mathrm{M}$ insulin in diabetics ( $\mathrm{p}=0.006$ and 0.018 ) but not at $10^{-10} \mathrm{M}$ insulin $(\mathrm{p}=0.21)$. There were no significant differences between diabetics and non-diabetics

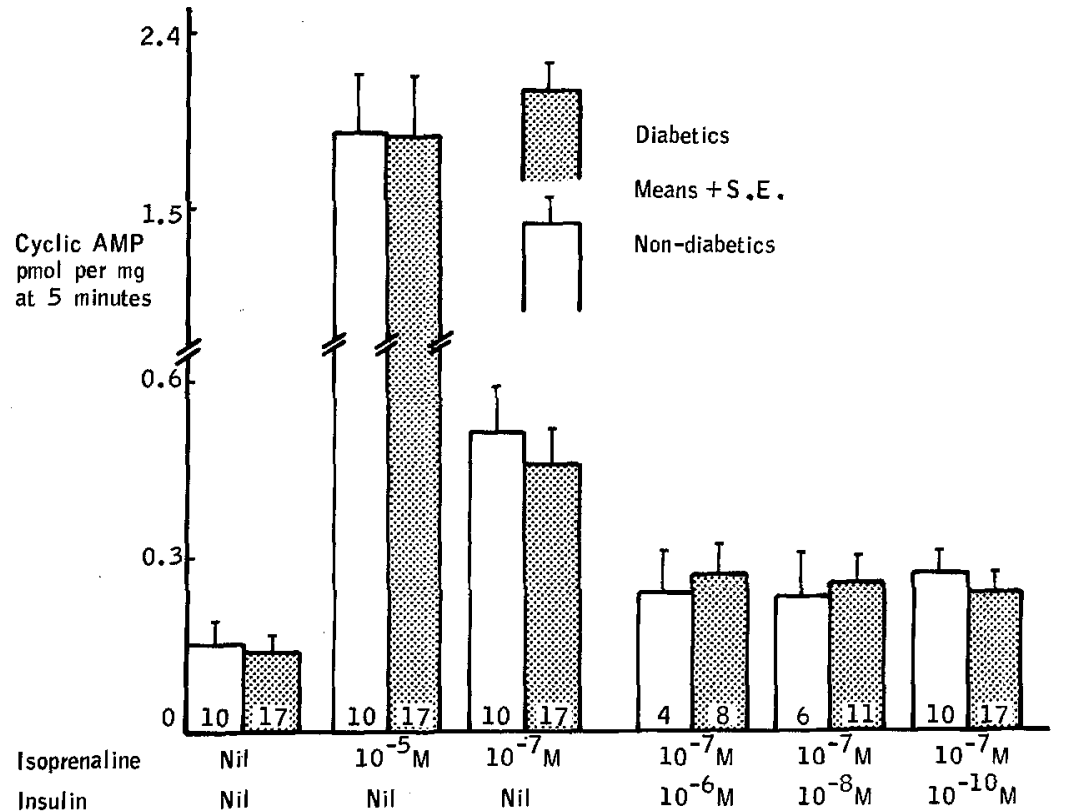

Fig. 6. The effect of insulin on cyclic AMP accumulation in adipose tissue of diabetic and non-diabetic patients. Incubation conditions are as in Figure 2. Insulin lowers cyclic AMP levels in adipose tissue of diabetics $\left(p<0.001,<0.02,<0.01\right.$ for insulin at $10^{-6}, 10^{-8}$ and $10^{-10} \mathrm{M}$ respectively) and in non-diabetics $\left(\mathrm{p}<0.01,<0.05,<0.06\right.$ respectively) compared to levels with isoprenaline alone $\left(10^{-7} \mathrm{M}\right)$

appears to be normal in adipose tissue of adult diabetics. Likewise, the sensitivity of the alpha-receptor appears to be normal in adult diabetics. Our techniques are sufficiently sensitive to demonstrate changes in catecholamine receptor sensitivity, and in hypothyroidism we have confirmed the results of Rosenquist et al. [2] on release of glycerol, demonstrating an increased alpha-receptor sensitivity in adipocytes, which can be reversed by treatment of patients with 1-thyroxine [4]. It is therefore unlikely that changes in catecholamine receptor sensitivity are responsible for the increased flux of plasma fatty acids that is frequently observed in adult diabetes. A number of reasons may account for the discrepancy between our results and those of Atkinson and Randle [5]. The severity of diabetes mellitus at time of study, 


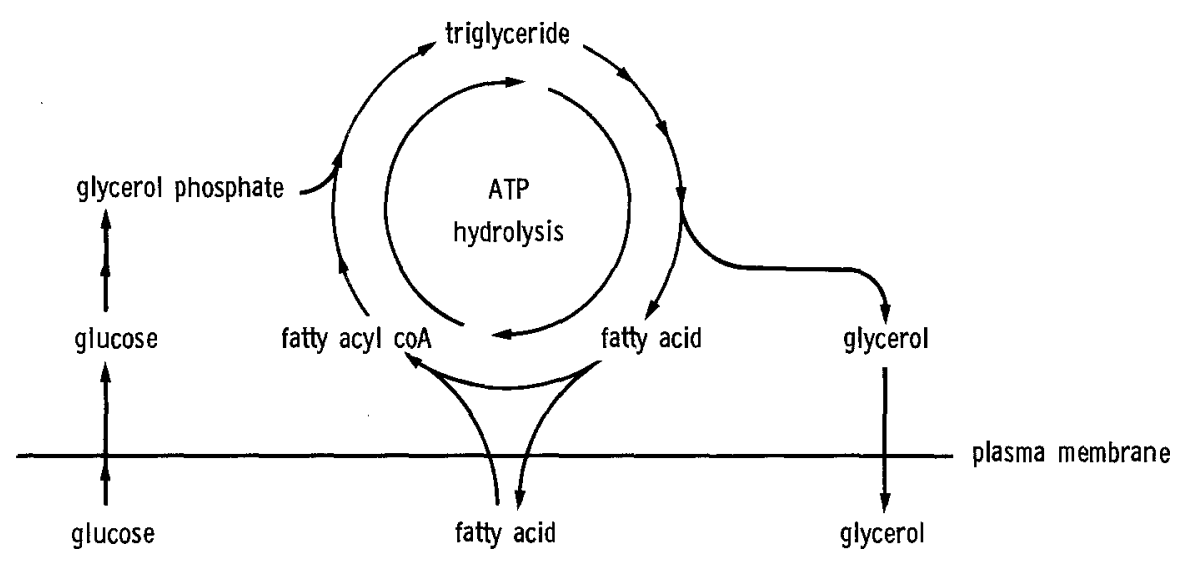

negative caloric balance and variations in age, obesity and adipocyte size may all influence lipolytic activity, and therefore produce variation of results in different studies. In particular, adipocyte size is an important factor for the effect of catecholamines on the lipolytic activity of cells; and large cells show a greater response than small cells [19]. However, we have examined our results as activities per million adipocytes and found no differences between diabetics and controls.

We have also examined the possibility that there is a failure of antilipolysis in adult diabetes; so that when lipolysis is activated it cannot be subsequently modulated or terminated.

Prostaglandins are synthesized from long chain polyunsaturated fatty acids in adipose tissue and are released during lipolysis [13]. It is possible that prostaglandins form part of a negative feedback loop inhibiting adenyl cyclase, which would then limit the extent or duration of lipolysis stimulated by catecholamines. This might constitute an example of product inhibition (since prostaglandins are derived from fatty acids) of the first step in the activation of lipolysis. However, the sensitivity of adenyl cyclase to inhibition by prostaglandin $E_{1}$ appears to be intact in adipose tissue of adult diabetics, as judged by the inhibition of levels of cyclic AMP and the reduction in output of glycerol and fatty acids from the tissue in vitro.

Insulin is another antilipolytic agent in human adipose tissue [14]. Although any second messenger mediating the intracellular effects of insulin is not known, consistent effects of insulin on tissue levels of cyclic AMP can be demonstrated [17]. This is unlikely to be a direct action of insulin on the activity of adenyl cyclase, but may be a secondary effect. In adult diabetes insulin $\left(10^{-10}-10^{-6} \mathrm{M}\right)$ produces a fall in tissue levels of cyclic AMP similar to that in non-diabetic controls. Tissue release of glycerol and fatty acids is similarly suppressed by insulin $\left(10^{-10}-10^{-6} \mathrm{M}\right)$ in diabetics and non-diabetics alike. Thus, from our in vitro data, it is unlikely that alterations in the regulation of lipolysis by activator or inhibitory agents is related to the increased plasma fatty acid flux of adult diabetes.

The regulation of fatty acid release from adipose tissue is a complex process and involves not only the pathways of lipolysis, but also the re-esterification pathway. The two pathways operate simultaneously in adipose tissue and constitute a glyceride-fatty acid shuttle (Fig. 7). Evidence that the shuttle may function in human adipose tissue can be seen from Figures . and 5, where the ratio of basal release of glycerol: fatty acids is less than three. (If the pathways were mutually exclusive the ratio would be approximately three). We have previously demonstrated a defect in the esterification segment of the shuttle in adipose tissue of adult diabetics [15, 16]; and this disorder of fatty acid esterification may more likely account for the increased plasma fatty acid flux in diabetes than changes in the lipolytic segment.

Acknowledgements. Grateful thanks are due to Professor J. Landon for encouragement and advice. Dr. D. J. Galton was supported by a grant from the British Diabetic Association, and Dr. J. P. D. Reckless by a Cooper-Coventon Scholarship from St. Bartholomew's Hospital.

\section{References}

1. Galton, D. J., Gilbert, C., Reckless, J. P. D., Kaye, J.: Triglyceride storage disease: A group of inborn errors of triglyceride metabolism. Quart. J. Med. 43, 63-71 (1974)

2. Rosenqvist, U., Efendic, S., Jereb, B., Ostman, J.: Influence of the hypothyroid state on lipolysis in human adipose tissue in vitro. Acta med. scand. 189, 381-384 (1971) 
3. Rosenqvist, U.: Inhibition of noradrenaline-induced lipolysis in hypothyroid subjects by increased alpha-adrenergic responsiveness. Acta med. scand. 19, 353-359 (1972)

4. Reckless, J. P. D., Gilbert, C. H., Galton, D. J.: Alpha-adrenergic activity on cyclic AMP levels and lipolysis in adipose tissue of hypothyroid man and rat. J. Endocr. 68, 419-430 (1976)

5. Atkinson, J. N. C., Randle, P. J.: An abnormality of adrenaline phentolamine stimulated lipolysis in adipose tissue from obese maturity-onset diabetics. Diabetologia 8, 371-376 (1972)

6. Gilbert, C. H., Kaye, J., Galton, D. J.: The effect of a glucose load on plasma fatty acids and lipolysis in adipose tissue of obese diabetic and non-diabetic patients. Diabetologia 10, 135-138 (1974)

7. Bierman, E. L., Dole, V. P., Roberts, T. N.: An abnormality of non-esterified fatty acid metabolism in diabetes mellitus. Diabetes 6, 475-479 (1957)

8. Diengott, D., Kerpel, S.: A new type of needle for obtaining large samples of human adipose tissue. J. Lipid Res. 8, 58-60 (1967)

9. Brown, M. E.: Ultra-micro sugar determinations using 2, 9-dimethyl-1, 10-phenanthroline hydrochloride (neocuproine). Diabetes 10, 60-62 (1961)

10. Garland, P. B., Randle, P. J.: A rapid enzymatic assay for glycerol. Nature (Lond.) 196, 987-988 (1962)

11. Carruthers, M., Young, D. A. B.: Free fatty acid estimation by a semiautomated fluorometric method. Clin. chim. Acta 49, 341-348 (1973)

12. Brown, B. L., Albano, J. D. M., Ekins, R. P., Scherzi, A. M., Tampion, W.: A simple and sensitive saturation assay method for the measurement of adenosine $3^{\prime}: 5^{\prime}$ cyclic monophosphate. Biochem. J. 121, 561-562 (1971)

13. Shaw, J. E., Ramwell, P. W.: Release of prostaglandin from rat epididymal fat pad on nervous and hormonal stimulation. J. biol. Chem. 243, 1498-1503 (1968)

14. Galton, D. J., Bray, G. A.: Studies on lipolysis in human adipose cells. J. clin. Invest. 46, 621-629 (1967)
15. Galton, D. J., Wilson, J. P. D., Kissebah, A. H.: The effect of adult diabetes on glucose utilization and esterification of palmitate by human adipose tissue. Europ. J. clin. Invest. 1, 399-404 (1971)

16. Clifton-Bligh, P., Galton, D. J.: The esterification of palmitate by adipose tissue of hypertriglyceridaemic patients with or without diabetes mellitus. Clin. Sci. Mol. Med. (in press)

17. Butcher, R. W., Baird, C. E., Sutherland, E. W.: Effects of lipolytic and anti-lipolytic substances on adenosine $3^{\prime}: 5^{\prime}$-monophosphate levels in isolated fat cells. J. biol. Chem. 243, 1705-1712 (1968)

18. Smith, U., Sjostrom, L., Bjorntorp, P.: Comparison of two methods for determining human adipose cell size. J. Lipid Res. 13, 822-824 (1972)

19. Jacobsson, B., Smith, U.: Effect of cell size on lipolysis and antilipolytic action of insulin in human fat cells. J. Lipid Res. 13, 651-656 (1972)

20. Siddle, K., Hales, C. N.: The effect of local anaesthetics on lipolysis in fat cells. Biochem. J. 130, 34 P (1972)

21. Östman, J., Efendic, S.: Catecholamines and metabolism of human adipose tissue. II. Effect of isopropylnoradrenaline and adrenergic blocking agents on lipolysis in human omental adipose tissue in vitro. Acta med. scand. 187, 471-476 (1970)

Received: January 26, 1976, and in revised form: May 19, 1976

Dr. D. J. Galton

Diabetes and Lipid Research Lab.

St. Bartholomew's Hospital

West Smithfield

London EC1A 7BE

England 